Atmos. Chem. Phys., 13, 1927-1939, 2013

www.atmos-chem-phys.net/13/1927/2013/

doi:10.5194/acp-13-1927-2013

(C) Author(s) 2013. CC Attribution 3.0 License.

\title{
Factors determining the formation of secondary inorganic aerosol: a case study in the Po Valley (Italy)
}

\author{
S. Squizzato ${ }^{1}$, M. Masiol ${ }^{1}$, A. Brunelli ${ }^{1}$, S. Pistollato ${ }^{2}$, E. Tarabotti ${ }^{2}$, G. Rampazzo ${ }^{1}$, and B. Pavoni ${ }^{1}$ \\ ${ }^{1}$ DAIS - Dipartimento di Scienze Ambientali, Informatica e Statistica, Università Ca' Foscari Venezia, Dorsoduro 2137, \\ 30123 Venice, Italy \\ ${ }^{2}$ Dipartimento Provinciale di Venezia, Agenzia Regionale per la Prevenzione e Protezione Ambientale del Veneto, Via Lissa \\ 6, 30174 Mestre, Italy
}

Correspondence to: B. Pavoni (brown@unive.it)

Received: 24 April 2012 - Published in Atmos. Chem. Phys. Discuss.: 4 July 2012

Revised: 24 January 2013 - Accepted: 25 January 2013 - Published: 19 February 2013

\begin{abstract}
.
Physicochemical properties of aerosol were investigated by analyzing the inorganic water soluble content in $\mathrm{PM}_{2.5}$ samples collected in the eastern part of the Po Valley (Italy). In this area the EU limits for many air pollutants are frequently exceeded as a consequence of local sources and regional-scale transport of secondary inorganic aerosol precursors. Nine $\mathrm{PM}_{2.5}$-bound major inorganic ions $\left(\mathrm{F}^{-}, \mathrm{Cl}^{-}\right.$, $\mathrm{NO}_{3}^{-}, \mathrm{SO}_{4}^{2-}, \mathrm{Na}^{+}, \mathrm{NH}_{4}^{+}, \mathrm{K}^{+}, \mathrm{Mg}^{2+}, \mathrm{Ca}^{2+}$ ) were monitored over one year in three sites categorized as semi-rural background, urban background and industrial. The acidic properties of the $\mathrm{PM}_{2.5}$ were studied by applying the recently developed E-AIM thermodynamic model 4 (Extended Aerosol Thermodynamics Model). The experimental data were also examined in relation to the levels of gaseous precursors of secondary inorganic aerosol $\left(\mathrm{SO}_{2}, \mathrm{NO}_{\mathrm{x}}, \mathrm{NO}\right.$, $\mathrm{NO}_{2}$ ) and on the basis of some environmental conditions having an effect on the secondary aerosols generation processes. A chemometric procedure using cluster analysis on experimental $\left[\mathrm{NH}_{4}^{+}\right] /\left[\mathrm{SO}_{4}^{2-}\right]$ molar ratio and $\mathrm{NO}_{3}^{-}$concentration has been applied to determine the conditions needed for ammonium nitrate formation in different chemical environments. Finally, some considerations on the secondary inorganic aerosol formation and the most relevant weather conditions concerning the sulfate-nitrate-ammonium system were also discussed. The obtained results and discussion can help in understanding the secondary aerosol formation dynamics in the Po Valley, which is one of the most critical regions for air pollution in southern Europe.
\end{abstract}

\section{Introduction}

The particulate matter (PM) is a multi-component system that includes materials in the solid or liquid states and enters the atmosphere from both natural and anthropogenic sources. It can play an important role in the Earth's radiation budget (Forster et al., 2007), dim the atmospheric visibility (Bäumer et al., 2008), be involved in acid deposition (Larssen et al., 2006), produce major threats to cultural heritage (Nava et al., 2010) and be linked with a variety of respiratory illnesses, cardiovascular problems and life-expectancy reduction (Pope et al., 2009). PM can be distinguished in primary, directly emitted from sources, and secondary, subsequently formed in the atmosphere from chemical processes involving a set of precursor gases. This latter fraction is, mainly generated through a series of chemical reactions and physical processes involving nitrogen oxides $\left(\mathrm{NO}_{\mathrm{x}}\right)$, sulfur dioxide $\left(\mathrm{SO}_{2}\right)$, ammonia $\left(\mathrm{NH}_{3}\right)$ and a large number of volatile organic compounds (VOCs), which may react with ozone $\left(\mathrm{O}_{3}\right)$, hydroxyl radical $(\cdot \mathrm{OH})$ and other reactive molecules forming the secondary inorganic aerosol (SIA) and secondary organic aerosol (SOA).

Sulfate $\left(\mathrm{SO}_{4}^{2-}\right)$, nitrate $\left(\mathrm{NO}_{3}^{-}\right)$and ammonium $\left(\mathrm{NH}_{4}^{+}\right)$are the main secondary inorganic aerosol (SIA) components in PM mainly occurring as ammonium sulfate $\left(\left(\mathrm{NH}_{4}\right)_{2} \mathrm{SO}_{4}\right)$ and ammonium nitrate $\left(\mathrm{NH}_{4} \mathrm{NO}_{3}\right)$, which are originated, respectively, by the neutralization of sulfuric acid $\left(\mathrm{H}_{2} \mathrm{SO}_{4}\right)$ and nitric acid $\left(\mathrm{HNO}_{3}\right)$ with ammonia (Stockwell et al., 2003). The neutralization of sulfuric acid generally prevails on the neutralization of nitric acid (Seinfeld and Pandis, 2006), but 
the production of secondary sulfates and/or nitrates strongly depends on several chemical and micro-meteorological factors, such as the levels of gaseous precursors, the concentrations of atmospheric oxidants, the characteristics of preexisting aerosols, the air temperature and humidity (Baek et al., 2004; Pathak et al., 2009). In Europe, non-marine sulfate and nitrate contribute for a large part to the mass of the fine particulate matter (with aerodynamic diameter less than $2.5 \mu \mathrm{m}, \mathrm{PM}_{2.5}$ ), ranging from $11 \%$ to $35 \%$ and from $1 \%$ to $24 \%$, respectively, (Putaud et al., 2010) and may also play a key role in the aerosol acidity and its negative effects on human health, ecosystems and materials. In coastal areas also, sea salts, mainly composed of $\mathrm{Cl}^{-}$and $\mathrm{Na}^{+}$, can influence $\mathrm{PM}_{2.5}$ levels and acidity. In Europe even when $95 \%$ of the total mass of marine aerosols is in the coarse mode (particles with aerodynamic diameter larger than $2.5 \mu \mathrm{m}$ ) (Seinfeld and Pandis, 2006), sea salt in $\mathrm{PM}_{2.5}$ ranges from less than $1 \%$ (in remote continental areas) to $11 \%$ (in Atlantic zones) (Putaud et al., 2010).

Since the annual limit fixed by the European Union for $\mathrm{PM}_{2.5}\left(25 \mu \mathrm{g} \mathrm{m}^{-3}\right.$ to be met in 2015; EC, 2008) is not, or not yet, achieved in several sites (EEA, 2012), the secondary aerosol and locally marine components are of major importance for the abatement measures to have their effect. Moreover, the knowledge of the atmospheric conditions influencing the SIA formation appear very important for deciding policies at both local and regional scales.

Several studies have quantified SIA in Europe (e.g., Putaud et al., 2004; Querol et al., 2004; Lonati et al., 2008) and studied its dispersion (e.g., Schaap et al., 2004a; Renner and Wolke, 2010), also considering gaseous pollutants (Bencs et al., 2008) and environmental conditions (Arsene et al., 2010). However, scarce information is available about the aerosol acidity. Moreover, ammonium nitrate formation was usually investigated using chemical equilibrium models mainly addressed to understand the partitioning between the gas and aerosol phases (e.g., Ansari and Pandis, 1999; Dassios and Pandis, 1999; Ansari and Pandis, 2000; Stockwell et al., 2000).

The presented data have been collected in the eastern part of the Po Valley, historically affected by amongst the heaviest levels of air pollution in Europe, in which the acidic properties of aerosol may have serious impacts on human health, environment and cultural heritage. The $\mathrm{PM}_{2.5}$ and its content in major inorganic ions were monitored in three sites of different typologies (urban background, industrial and semirural background) near Venice (Italy), in the eastern border of the Po Valley, in the middle of a coastal lagoon, where $\mathrm{PM}_{2.5}$ levels frequently exceed the EU limits and heavy levels of SIA components and sea salts are observed (Prodi et al., 2009; Squizzato et al., 2012; Masiol et al., 2012a).

In this study the aerosol formation processes and acidity properties were studied using chemical experimental data (ion and gaseous precursors concentrations), readily available meteorological information, and a thermodynamic model. At first aerosol acidity was modeled using the recently released thermodynamic model E-AIM4 (Extended Aerosol Thermodynamics Model). Afterwards, the sulfatenitrate-ammonium system and the subsequent SIA generation processes have been investigated by a chemometric procedure to explain the environmental and chemical conditions favoring the ammonium nitrate formation. Finally, the experimental ion data were examined in relation to the levels of gaseous precursors of SIA $\left(\mathrm{SO}_{2}, \mathrm{NO}_{\mathrm{x}}, \mathrm{NO}, \mathrm{NO}_{2}\right)$ and considering some environmental conditions having an effect on SIA generation processes. The obtained results and discussion can help understanding the secondary aerosol formation dynamics in the Po Valley, which is one of the most critical regions for air pollution in southern Europe.

\section{Study area}

The historical city center of Venice, settled in the middle of a $\sim 550 \mathrm{~km}^{2}$-wide coastal lagoon and intensely inhabited since the 15th century, is one of the major touristic destinations in Italy. At present it suffers from numerous anthropogenic pressures including coastal erosion, sediment and water contamination, eutrophication, exploitation of biological resources, and air pollution. The main local anthropogenic activities influencing air quality in the Venice area are linked to domestic heating from urban areas $(\sim 270000$ inhabitants), emissions from the industrial zone of Porto Marghera including chemicals, metallurgical factories, oil refineries, coal and gas power plants, traffic exhaust from a frequently congested road network, artistic glass-making factories in the Island of Murano, shipping emissions from public and private boats, industrial and passenger terminals and flying traffic from an international airport (Rampazzo et al., 2008a,b). Natural contributions add crustal, marine and biological materials. Recently, the importance of the regionalscale transports of pollutants from the Po Valley and the transboundary transports from Eastern and Central Europe were also evidenced and assessed (Masiol et al., 2010; Squizzato et al., 2012; Masiol et al., 2012a).

The most recent emission inventory (2005) published by Istituto Superiore per la Protezione e la Ricerca Ambientale ISPRA (2012) for the Venice area has reported that in the study area, the fossil fuel combustion in energy and transformation industries and transportation emits several $\mathrm{Gg} \mathrm{yr}^{-1}$ of $\mathrm{SO}_{\mathrm{x}}\left(\mathrm{SO}_{2}+\mathrm{SO}_{3}\right)$ and $\mathrm{NO}_{\mathrm{x}}$, i.e., the gaseous precursors of SIA.

\section{Materials and methods}

\subsection{Sampling sites}

The sampling sites were selected to characterize different emissive scenarios (Fig. 1). A semi-rural coastal background site (SRC, Lat. $45.4227^{\circ} \mathrm{N}$-Long. $12.4368^{\circ} \mathrm{E}$ ) upwind of 


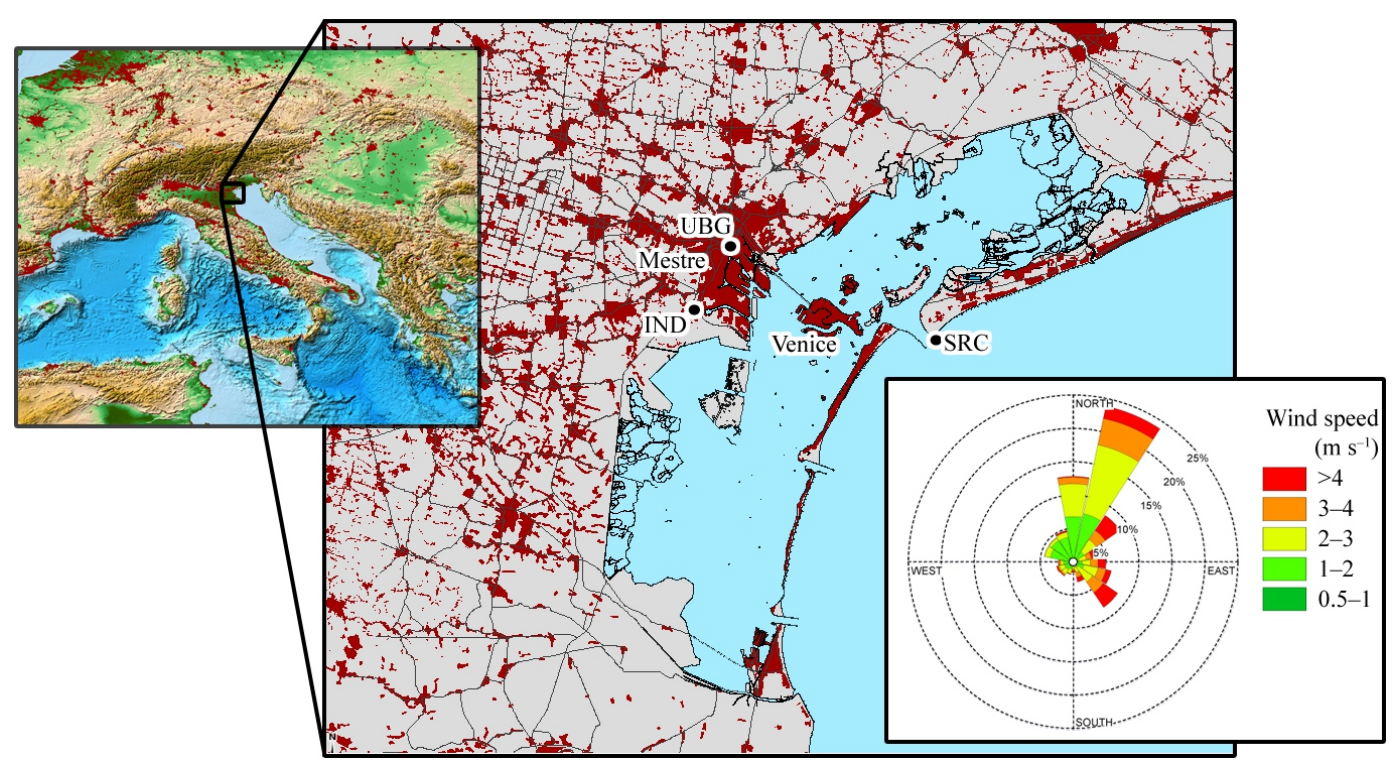

Fig. 1. Study area and wind rose computed for 2009. The main urban settlements are red colored.

main emission sources was set on a lighthouse on the Adriatic coastline. A second site was placed in a high density residential zone to be representative of an urban background (UBG, Lat. $45.4871^{\circ} \mathrm{N}$-Long. $12.2229^{\circ} \mathrm{E}$ ). A third site was selected close to the main industrial area of Porto Marghera for being representative of industrial emissions (IND, Lat. $45.4382^{\circ} \mathrm{N}$-Long. $12.2055^{\circ} \mathrm{E}$ ).

\subsection{Analytical}

A $\mathrm{PM}_{2.5}$ sampling campaign was started in January 2009 and lasted one year. Samples were collected simultaneously in the three sites on $47 \mathrm{~mm}$ quartz fiber filters (Whatman QMA, GE Healthcare, USA) using low-volume automated samplers set according to EN 14907 standards $\left(2.3 \mathrm{~m}^{3} \mathrm{~h}^{-1}\right)$. Sampling time was $24 \mathrm{~h}$, from 0:00 to 24:00. $\mathrm{PM}_{2.5}$ masses were obtained by gravimetric determination on filters preconditioned at constant temperature $\left(20 \pm 5^{\circ} \mathrm{C}\right)$ and humidity (RH $50 \pm 5 \%$ ) for at least $48 \mathrm{~h}$. After sampling, filters were stored at $-20^{\circ} \mathrm{C}$ in the dark until analyses to avoid contamination and loss of the most volatile compounds.

Four periods representative of different seasons, weather conditions and emissions were selected: spring (37 days, March-April 2009), summer (36 days, June-July 2009), autumn (42 days, September-October 2009) and winter (41 days, December 2009-January 2010). These samples (150 for each sampling site, 445 in total) were prepared using ultrasonic-assisted dissolution in $15 \mathrm{ml}$ ultrapure water (resistivity $\approx 18 \mathrm{M} \Omega \mathrm{cm}$ ) and then analyzed on an ion chromatographic system (Dionex DX500, USA) for quantifying nine major inorganic ions $\left(\mathrm{F}^{-}, \mathrm{Cl}^{-}, \mathrm{NO}_{3}^{-}, \mathrm{SO}_{4}^{2-}, \mathrm{Na}^{+}, \mathrm{NH}_{4}^{+}, \mathrm{K}^{+}\right.$, $\left.\mathrm{Mg}^{2+}, \mathrm{Ca}^{2+}\right)$. Details of analytical procedures and instrumental setup are given elsewhere (Squizzato et al., 2012).
Sea-salt sulfate $\left(\mathrm{ssSO}_{4}^{2-}\right)$ and non sea-salt sulfate $\left(\mathrm{nssSO}_{4}^{2-}\right)$ were indirectly calculated using the seawater ratio assuming that $\mathrm{Na}^{+}$was dominated by sea-salt emissions as

$$
\begin{aligned}
\mathrm{ssSO}_{4}^{2-} & =0.25 \cdot \mathrm{Na}^{+} \\
\mathrm{nssSO}_{4}^{2-} & =\mathrm{SO}_{4}^{2-}-\mathrm{ssSO}_{4}^{2-} .
\end{aligned}
$$

In UBG and IND sites, the main gaseous SIA precursors $\left(\mathrm{SO}_{2}, \mathrm{NO}_{\mathrm{x}}, \mathrm{NO}, \mathrm{NO}_{2}\right)$ were hourly measured by the local environmental protection agency (ARPAV) network. Ultraviolet fluorescence was used for $\mathrm{SO}_{2}$ (Model 43A, Thermo Electron Co., USA) and chemiluminescence for nitrogen oxides (Model 42C, Thermo Electron Co., USA), following the EN 14212 and EN 14211 standards, respectively.

\subsection{Thermodynamic model}

The aerosol acidity is one of the most important parameters influencing atmospheric chemistry and physics, and the determination of in situ aerosol properties as acidity and water content is fundamental to investigate the aerosol acidity characteristics and the role of heterogeneous chemistry in nitrate formation (Pathak et al., 2009). Previous studies (Zhang et al., 2000; Pathak et al., 2004; Zhang et al., 2007; Pathak et al., 2009; Engelhart et al., 2011; Pathak et al., 2011) applied the Extended Aerosol Inorganic Model (E-AIM, http: //www.aim.env.uea.ac.uk/aim/aim.php; Clegg et al., 1998) to simulate the in situ acidity $\left(\left[\mathrm{H}^{+}\right]_{\text {ins }}\right)$, the aerosol water content (AWC) and the activities of ionic species in aqueous aerosols and the solid- and liquid-phase compositions. In this study, we used the E-AIM model IV (E-AIM4) recently developed by Friese and Ebel (2010) for $\mathrm{H}^{+}-\mathrm{NH}_{4}^{+}-\mathrm{Na}^{+}-$ $\mathrm{SO}_{4}^{2-}-\mathrm{NO}_{3}^{-}-\mathrm{Cl}^{-}-\mathrm{H}_{2} \mathrm{O}$ mixtures to simulate the acidity and 
thermodynamic properties of $\mathrm{PM}_{2.5}$. The average ambient temperature, relative humidity, and average molar concentrations of total aerosol acidity $\left(\left[\mathrm{H}^{+}\right]_{\text {Total }}\right)$ and experimental data were used as the input in E-AIM4 to obtain $\left[\mathrm{H}^{+}\right]_{\text {ins }}$ and the moles of chemical species in aqueous phase. In this study, $\left[\mathrm{H}^{+}\right]_{\text {Total }}$ was estimated using the ionic balance of the most relevant inorganic ionic species (Lippmann et al., 2000; Pathak et al., 2009), including sulfate, nitrate, chloride, ammonium and sodium:

$[\mathrm{H}]_{\text {Total }}^{+}=2 \cdot \mathrm{SO}_{4}^{2-}+\mathrm{NO}_{3}^{-}+\mathrm{Cl}^{-}-\left(\mathrm{NH}_{4}^{+}+\mathrm{Na}^{+}\right)$.

Samples characterized by total acidity equal or less than zero were not modeled. Starting from the model outputs, the in situ $\mathrm{pH}$ of aerosols was estimated as

$\mathrm{pH}=-\log \left(f \mathrm{H}_{\mathrm{aq}}^{+} \cdot x \mathrm{H}_{\mathrm{aq}}^{+}\right)$,

where $f$ is the activity coefficient on mole fraction basis and $x$ is the mole fractions of aqueous particle phase $\mathrm{H}^{+}$(Zhang et al., 2007).

\subsection{Potential sampling artifacts}

Under certain conditions of temperature and humidity, some artifacts can occur on the filters related to the interaction between the particles collected, the interaction between gas and particles, the capture of gas by the filter and evaporation of volatile and semi-volatile substances. These interactions can alter the composition of the collected particles. Ammonium sulfate can be considered as a conservative species (i.e., not subject to adsorption or volatilization), whereas ammonium nitrate is a semi-volatile species and exists in a reversible phase equilibrium with nitric acid in the gas phase. Hence, the concentrations of aerosol nitrate can be affected by the evaporative loss of the semi-volatile ammonium nitrate (negative artifact) or adsorption of nitric acid gas during or after the sampling (positive artifact); however, nitrate volatilization generally dominates over adsorption (Schaap et al., 2004b; Vecchi et al., 2009).

Depending on the composition of the aerosol, the temperature and relative humidity, the sampling artifacts for the ammonium nitrate can become significant (Pathak et al., 2009). Teflon filters are characterized by evaporation losses of ammonium nitrate even at low temperature, whereas quartz filters show a good retention up to $20^{\circ} \mathrm{C}$ (Schaap et al., 2004b). Considering the average environmental temperatures of the study area, quartz filters have been used in the sampling campaign to minimize artifacts.

A study conducted in the Po Valley in different environmental conditions showed that the evaporative loss of aerosol nitrate from the quartz filters is a function of temperature. At temperatures exceeding $25^{\circ} \mathrm{C}$ evaporation is almost complete, whereas retention is dominant at temperature below $20^{\circ} \mathrm{C}$ (Schaap et al., 2004b). In addition, experimental results presented by Vecchi et al. (2009) showed that negative artifacts due to nitrate volatilization from the filters were on average $22 \%$ on quartz filters in summer, and no or negligible losses were observed in winter.

On the basis of the measured temperatures averaged over the $24 \mathrm{~h}$, only some summer samples ( 95 of 445 ), with average daily temperatures $\geq 20^{\circ} \mathrm{C}$, could have undergone sampling artifacts. The evaporative loss of aerosol nitrate on summer samples has been estimated following the empirical correlations proposed in Pathak and Chan (2005) and Pathak et al. (2009); $\mathrm{H}^{+}$has been estimated using the ionic balance. For ammonium-rich samples

Nitrate loss $(\%)=30 \cdot\left[\ln \left(\frac{\left[\mathrm{NH}_{4}^{+}\right]}{\left[\mathrm{NO}_{3}^{-}\right]}\right)-1.2\right]$,

and for ammonium-poor samples:

Nitrate loss $(\%)=30 \cdot\left[\ln \left(\frac{\left[\mathrm{H}^{+}\right]}{\left[\mathrm{NO}_{3}^{-}\right]}\right)-1.2\right]$.

On this basis the average aerosol nitrate loss was $26 \% \pm 7$ and $20 \% \pm 6$ in ammonium-rich and ammonium-poor samples, respectively, in accordance with Vecchi et al. (2009). A one-way ANOVA has been performed to compare raw data and data corrected for aerosol nitrate loss. Results showed no significant difference $(p$-value $=0.916)$. Both cluster analysis discussed and aerosol acidity calculation have been done on raw data and then repeated on corrected data to control artifact effects, but no significant difference has been observed in terms of seasonal mean and standard deviation.

\section{Results and discussion}

\subsection{Seasonal variations of gases and ionic species in $\mathbf{P M}_{2.5}$}

Some statistics of analytical data are summarized in Table 1. The industrial site presents higher annual average concentrations of $\mathrm{SO}_{2}, \mathrm{NO}_{\mathrm{x}}$ and $\mathrm{NO}\left(6,82\right.$ and $28 \mu \mathrm{g} \mathrm{m}^{-3}$ respectively) than UBG $\left(4,75\right.$ and $\left.22 \mu \mathrm{g} \mathrm{m}^{-3}\right)$. Conversely, higher annual average concentrations of $\mathrm{NO}_{2}$ were observed in UBG $\left(44 \mu \mathrm{g} \mathrm{m}^{-3}\right)$ than in IND $\left(38 \mu \mathrm{g} \mathrm{m}^{-3}\right)$. The annual limit value fixed by the European Union $\left(40 \mu \mathrm{g} \mathrm{m}^{-3}, \mathrm{EC}, 2008\right)$ for $\mathrm{NO}_{2}$ was exceeded only in UBG. Nitrogen oxides showed typical seasonal trends depending on changes in photochemistry and in emission rates, i.e., higher levels during the coldest months. Differently, no significant variations were recorded for $\mathrm{SO}_{2}$. The $\mathrm{PM}_{2.5}$ annual average mass was $33 \mu \mathrm{g} \mathrm{m}{ }^{-3}$ for the two mainland sites (UBG, IND) and $26 \mu \mathrm{g} \mathrm{m}^{-3}$ for SRC. $\mathrm{PM}_{2.5}$ concentrations were inversely correlated with air temperature, with higher levels during the cold period (Table 1). Comparing these results with other data (ARPAV, 2010a,b), available since 2008 for URB and IND, seasonal means have apparently dropped from January to October, and conversely increased in November and December. $\mathrm{PM}_{2.5}$ 
Table 1. Descriptive statistics (mean \pm standard deviation) of experimental data (gases, ions, weather parameters), neutralization ratio, $\left[\mathrm{H}^{+}\right]_{\text {Strong }}$, E-AIM4 results $\left(\left[\mathrm{H}^{+}\right]_{\text {Free }}, \mathrm{pH}\right)$ and oxidation ratios (SOR and NOR).

\begin{tabular}{|c|c|c|c|c|c|c|c|}
\hline \multirow[b]{2}{*}{$N$} & & \multicolumn{3}{|c|}{ Spring } & \multicolumn{3}{|c|}{ Summer } \\
\hline & & $\begin{array}{c}\text { SRC } \\
37\end{array}$ & $\begin{array}{c}\text { UBG } \\
37\end{array}$ & $\begin{array}{c}\text { IND } \\
30\end{array}$ & $\begin{array}{c}\text { SRC } \\
36\end{array}$ & $\begin{array}{c}\text { UBG } \\
36\end{array}$ & $\begin{array}{c}\text { IND } \\
31 \\
\end{array}$ \\
\hline $\mathrm{PM}_{2.5}$ & $\mu \mathrm{g} \mathrm{m}^{-3}$ & $26.8 \pm 22.1$ & $36.8 \pm 31.3$ & $32.0 \pm 17.7$ & $11.2 \pm 4.7$ & $14.5 \pm 4.8$ & $17.9 \pm 14.2$ \\
\hline $\mathrm{SO}_{4}^{2-}$ & $\mu \mathrm{g} \mathrm{m}^{-3}$ & $2.4 \pm 1.3$ & $2.4 \pm 1.8$ & $2.4 \pm 1.0$ & $2.7 \pm 1.5$ & $2.7 \pm 1.6$ & $3.4 \pm 3.7$ \\
\hline $\mathrm{ssSO}_{4}^{2-}$ & $\mu \mathrm{g} \mathrm{m}^{-3}$ & $0.05 \pm 0.03$ & $0.07 \pm 0.07$ & $0.13 \pm 0.11$ & $0.03 \pm 0.02$ & $0.07 \pm 0.08$ & $0.07 \pm 0.05$ \\
\hline $\mathrm{nssSO}_{4}^{2-}$ & $\mu \mathrm{g} \mathrm{m}^{-3}$ & $2.3 \pm 1.3$ & $2.3 \pm 1.8$ & $2.3 \pm 1.0$ & $2.7 \pm 1.5$ & $2.6 \pm 1.6$ & $3.7 \pm 3.7$ \\
\hline $\mathrm{NO}_{3}^{-}$ & $\mu \mathrm{g} \mathrm{m}^{-3}$ & $5.8 \pm 6.4$ & $6.4 \pm 8.3$ & $5.4 \pm 4.2$ & $0.9 \pm 0.7$ & $0.5 \pm 0.5$ & $0.7 \pm 0.8$ \\
\hline $\mathrm{NH}_{4}^{+}$ & $\mu \mathrm{g} \mathrm{m}^{-3}$ & $2.2 \pm 2.0$ & $2.4 \pm 2.8$ & $2.3 \pm 1.3$ & $1.1 \pm 0.7$ & $1.0 \pm 0.6$ & $0.9 \pm 0.5$ \\
\hline SIA $^{4}$ & $\mu \mathrm{g} \mathrm{m}^{-3}$ & $10.2 \pm 9.5$ & $11.1 \pm 12.6$ & $10.0 \pm 5.9$ & $4.6 \pm 2.3$ & $4.1 \pm 2.2$ & $4.9 \pm 4.5$ \\
\hline SIA/PM 2.5 & $\%$ & $36.3 \pm 5.7$ & $26.4 \pm 8.6$ & $31.7 \pm 8.7$ & $41.5 \pm 10.7$ & $26.4 \pm 7.5$ & $26.1 \pm 6.1$ \\
\hline $\mathrm{SO}_{2}$ & $\mu \mathrm{gm}^{-3}$ & - & $4.6 \pm 3.2$ & $6.6 \pm 4.0$ & - & $5.3 \pm 3.8$ & $5.0 \pm 3.2$ \\
\hline $\mathrm{NO}$ & $\mu \mathrm{g} \mathrm{m}^{-3}$ & - & $20.5 \pm 20.6$ & $27.5 \pm 23.7$ & - & $3.4 \pm 3.4$ & $7.4 \pm 4.7$ \\
\hline $\mathrm{NO}_{2}$ & $\mu \mathrm{g} \mathrm{m}^{-3}$ & - & $48.1 \pm 15.4$ & $34.6 \pm 11.5$ & - & $36.1 \pm 9.3$ & $29.4 \pm 6.3$ \\
\hline $\mathrm{NO}_{\mathrm{x}}$ & $\mu \mathrm{g} \mathrm{m}^{-3}$ & - & $73.1 \pm 44.6$ & $76.9 \pm 46.8$ & - & $32.0 \pm 13.4$ & $40.7 \pm 12.2$ \\
\hline$T$ & ${ }^{\circ} \mathrm{C}$ & $9.0 \pm 2.2$ & $10.5 \pm 2.2$ & $10.8 \pm 2.2$ & $22.6 \pm 2.1$ & $24.6 \pm 2.2$ & $24.2 \pm 2.2$ \\
\hline $\mathrm{RH}$ & $\%$ & $82.2 \pm 13.7$ & $78.7 \pm 13.5$ & $76.0 \pm 13.4$ & $79.0 \pm 7.8$ & $74.7 \pm 6.0$ & $74.9 \pm 6.1$ \\
\hline NR & - & $0.8 \pm 0.2$ & $0.8 \pm 0.2$ & $0.9 \pm 0.2$ & $0.8 \pm 0.2$ & $0.8 \pm 0.1$ & $0.7 \pm 0.3$ \\
\hline$N$ & & 29 & 26 & 18 & 30 & 20 & 19 \\
\hline$\left[\mathrm{H}^{+}\right]_{\text {Strong }}$ & $\mathrm{nmolm}^{-3}$ & $28.7 \pm 26.9$ & $22.1 \pm 25.2$ & $19.5 \pm 21.0$ & $9.4 \pm 6.3$ & $7.8 \pm 6.0$ & $12.1 \pm 10.7$ \\
\hline$\left[\mathrm{H}^{+}\right]_{\text {Free }}$ & $\mathrm{nmolm}^{-3}$ & $6.1 \pm 12.2$ & $2.9 \pm 4.7$ & $0.2 \pm 0.1$ & $1.2 \pm 1.1$ & $1.2 \pm 1.0$ & $2.0 \pm 1.7$ \\
\hline $\mathrm{pH}$ & - & $3.4 \pm 0.7$ & $3.6 \pm 0.4$ & $3.9 \pm 0.1$ & $2.5 \pm 0.7$ & $2.3 \pm 0.5$ & $2.0 \pm 0.5$ \\
\hline$N$ & & - & 37 & 30 & - & 36 & 31 \\
\hline SOR & - & - & $0.28 \pm 0.16$ & $0.22 \pm 0.09$ & - & $0.28 \pm 0.13$ & $0.31 \pm 0.20$ \\
\hline NOR & - & - & $0.07 \pm 0.07$ & $0.10 \pm 0.05$ & - & $0.01 \pm 0.01$ & $0.02 \pm 0.02$ \\
\hline
\end{tabular}

was strongly correlated in the three sites with similar levels in UBG and IND. On an annual basis, the secondary inorganic aerosol (SIA) given as the sum of $\mathrm{nssSO}_{4}^{2-}, \mathrm{NO}_{3}^{-}$ and $\mathrm{NH}_{4}^{+}$accounts for $9.5 \mu \mathrm{g} \mathrm{m}^{-3}$ (27\% of $\mathrm{PM}_{2.5}$ mass) in $\mathrm{UBG}, 9.6 \mu \mathrm{g} \mathrm{m}^{-3}(28 \%)$ in IND and $9.5 \mu \mathrm{g} \mathrm{m}^{-3}(36 \%)$ in SRC. Other analyzed anions $\left(\mathrm{F}^{-}\right.$and $\left.\mathrm{Cl}^{-}\right)$account for about $0.3 \mu \mathrm{g} \mathrm{m}^{-3}(1 \%)$ of the $\mathrm{PM}_{2.5}$ mass, whereas on average other cations (sum of $\mathrm{Na}^{+}, \mathrm{K}^{+}, \mathrm{Mg}^{2+}, \mathrm{Ca}^{2+}$ ) generally do not exceed $0.7 \mu \mathrm{g} \mathrm{m}^{-3}$. Sulfate, nitrate, and ammonium contributed to about $85 \%$ of the total inorganic ionic species mass in all the sites. Other anions and cations contributed for a minor fraction of the water-soluble species ( 2 and $7 \%$, respectively) in all sites. On a seasonal basis, the percentage of SIA contribution to $\mathrm{PM}_{2.5}$ mass shows no significant variations except in SRC (Fig. 2), neither does the contribution of ammonium to SIA. A difference is evident for the abundance of the nitrate compared to the sulfate: sulfate dominates on the nitrate in summer and autumn. In spring and winter, in correspondence with a PM increase, nitrate dominates on sulfate.

\subsection{Aerosol acidity}

Acidic aerosols have been widely observed in the atmosphere and can lead to significant consequences for both human health and ecosystems. They tend to be more hygroscopic than the neutral ones, and this enhances their ability to reflect light and act as condensation nuclei in the formation of droplets and clouds, which in turn enhances their influence on visibility and climate (Pathak et al., 2004; Zhang et al., 2007). Furthermore, acidic surfaces on atmospheric aerosols lead to potential increases in the mass of secondary organic aerosol (SOA). In fact, laboratory observations of enhancement in SOA mass concentrations related to an increase in acidity of inorganic seed aerosol suggest the presence of acid-catalyzed, particle-phase reactions (Zhang et al., 2007; Surrat et al., 2007).

Aerosol acidity depends on strong acid content, mainly sulfuric and nitric acids, whose precursors occur both in gas and aqueous phases. Aerosol acidity characteristics can be summarized as follows: (i) strong acidity $\left[\mathrm{H}^{+}\right]_{\text {Strong }}$, representing the sum of strong acids $\left(\mathrm{H}_{2} \mathrm{SO}_{4}, \mathrm{HNO}_{3}\right)$ in the water extract; (ii) free acidity $\left[\mathrm{H}^{+}\right]_{\text {Free }}$, defined as the moles of free 
Table 1. Continued.

\begin{tabular}{|c|c|c|c|c|c|c|c|}
\hline \multirow[b]{3}{*}{$N$} & & \multicolumn{3}{|c|}{ Autumn } & \multicolumn{3}{|c|}{ Winter } \\
\hline & & SRC & UBG & IND & SRC & UBG & IND \\
\hline & & 40 & 38 & 42 & 41 & 38 & 41 \\
\hline $\mathrm{PM}_{2.5}$ & $\mu \mathrm{g} \mathrm{m}^{-3}$ & $26.0 \pm 18.2$ & $29.6 \pm 16.2$ & $29.5 \pm 14.9$ & $38.8 \pm 15.7$ & $50.6 \pm 21.4$ & $49.3 \pm 20.3$ \\
\hline $\mathrm{SO}_{4}^{2-}$ & $\mu \mathrm{g} \mathrm{m}^{-3}$ & $4.6 \pm 3.6$ & $4.3 \pm 3.2$ & $4.4 \pm 3.4$ & $4.1 \pm 2.9$ & $3.8 \pm 2.6$ & $3.9 \pm 2.3$ \\
\hline $\mathrm{ssSO}_{4}^{2-}$ & $\mu \mathrm{g} \mathrm{m}^{-3}$ & $0.11 \pm 0.08$ & $0.04 \pm 0.01$ & $0.03 \pm 0.01$ & $0.05 \pm 0.05$ & $0.04 \pm 0.02$ & $0.03 \pm 0.01$ \\
\hline $\mathrm{nssSO}_{4}^{2-}$ & $\mu \mathrm{g} \mathrm{m}^{-3}$ & $4.5 \pm 3.6$ & $4.3 \pm 3.2$ & $4.4 \pm 3.4$ & $4.1 \pm 2.9$ & $3.8 \pm 2.6$ & $3.9 \pm 2.3$ \\
\hline $\mathrm{NO}_{3}^{-}$ & $\mu \mathrm{g} \mathrm{m}^{-3}$ & $3.5 \pm 5.1$ & $2.9 \pm 4.5$ & $2.7 \pm 3.9$ & $5.2 \pm 3.4$ & $6.1 \pm 3.9$ & $5.7 \pm 3.6$ \\
\hline $\mathrm{NH}_{4}^{+}$ & $\mu \mathrm{g} \mathrm{m}^{-3}$ & $2.6 \pm 2.2$ & $2.4 \pm 2.0$ & $2.3 \pm 1.9$ & $2.9 \pm 1.7$ & $3.3 \pm 1.6$ & $3.4 \pm 1.6$ \\
\hline SIA & $\mu \mathrm{g} \mathrm{m}^{-3}$ & $10.6 \pm 9.1$ & $9.6 \pm 8.1$ & $9.4 \pm 7.5$ & $12.2 \pm 6.7$ & $13.1 \pm 7.0$ & $12.9 \pm 6.4$ \\
\hline SIA/PM 2.5 & $\%$ & $36.1 \pm 10.3$ & $28.3 \pm 11.6$ & $28.5 \pm 12.0$ & $30.3 \pm 9.3$ & $25.8 \pm 7.7$ & $26.6 \pm 8.1$ \\
\hline $\mathrm{SO}_{2}$ & $\mu \mathrm{g} \mathrm{m}^{-3}$ & - & $2.1 \pm 2.3$ & $5.6 \pm 5.3$ & - & $3.5 \pm 2.1$ & $5.5 \pm 4.1$ \\
\hline NO & $\mu \mathrm{g} \mathrm{m}^{-3}$ & - & $19.9 \pm 21.4$ & $28.0 \pm 24.2$ & - & $35.0 \pm 23.1$ & $46.1 \pm 31.0$ \\
\hline $\mathrm{NO}_{2}$ & $\mu \mathrm{g} \mathrm{m}^{-3}$ & - & $41.6 \pm 10.0$ & $38.1 \pm 8.5$ & - & $47.6 \pm 12.4$ & $47.2 \pm 10.8$ \\
\hline $\mathrm{NO}_{\mathrm{x}}$ & $\mu \mathrm{gm}^{-3}$ & - & $19.9 \pm 21.4$ & $81.0 \pm 42.7$ & - & $35.0 \pm 23.1$ & $117.9 \pm 55.3$ \\
\hline$T$ & ${ }^{\circ} \mathrm{C}$ & $16.6 \pm 4.3$ & $17.6 \pm 4.0$ & $17.0 \pm 4.3$ & $3.3 \pm 2.5$ & $3.7 \pm 2.4$ & $3.7 \pm 2.6$ \\
\hline RH & $\%$ & $79.4 \pm 12.7$ & $77.1 \pm 11.7$ & $76.4 \pm 11.4$ & $88.9 \pm 10.4$ & $85.5 \pm 10.8$ & $85.3 \pm 10.9$ \\
\hline NR & - & $0.9 \pm 0.2$ & $0.9 \pm 0.2$ & $0.9 \pm 0.2$ & $0.9 \pm 0.2$ & $1.1 \pm 0.2$ & $1.1 \pm 0.1$ \\
\hline$N$ & & 15 & 19 & 28 & 34 & 14 & 15 \\
\hline$\left[\mathrm{H}^{+}\right]_{\text {Strong }}$ & $\mathrm{nmolm}^{-3}$ & $8.2 \pm 3.8$ & $5.6 \pm 3.8$ & $10.9 \pm 14.3$ & $18.7 \pm 11.6$ & $36.0 \pm 50.8$ & $11.5 \pm 13.8$ \\
\hline$\left[\mathrm{H}^{+}\right]_{\text {Free }}$ & $\mathrm{nmolm}^{-3}$ & $1.8 \pm 1.0$ & $0.9 \pm 0.6$ & $2.3 \pm 5.2$ & $3.5 \pm 5.9$ & $8.0 \pm 17.4$ & $1.9 \pm 4.6$ \\
\hline $\mathrm{pH}$ & - & $3.2 \pm 0.9$ & $3.1 \pm 0.6$ & $2.7 \pm 0.7$ & $3.6 \pm 0.3$ & $3.5 \pm 0.5$ & $3.8 \pm 0.3$ \\
\hline$N$ & & - & 38 & 42 & - & 38 & 41 \\
\hline SOR & - & - & $0.62 \pm 0.25$ & $0.35 \pm 0.23$ & - & $0.41 \pm 0.19$ & $0.38 \pm 0.19$ \\
\hline NOR & - & - & $0.04 \pm 0.05$ & $0.05 \pm 0.06$ & - & $0.08 \pm 0.04$ & $0.08 \pm 0.04$ \\
\hline
\end{tabular}

Table 2. Comparison of aerosol acidity between data observed in this study and in Pathak et al. (2009).

\begin{tabular}{|c|c|c|c|c|c|c|c|c|}
\hline Site & & SRC & UBG & IND & Beijing & Shanghai & Lanzhou & Guangzhou \\
\hline$\left[\mathrm{H}^{+}\right]_{\text {Strong }}$ & $\mathrm{nmolm}^{-3}$ & $9.4 \pm 6.3$ & $7.8 \pm 6.0$ & $12.1 \pm 10.7$ & $390 \pm 545$ & $220 \pm 225$ & $65 \pm 44$ & $70 \pm 58$ \\
\hline$\left[\mathrm{H}^{+}\right]_{\text {Free }}$ & $\mathrm{nmolm}^{-3}$ & $1.2 \pm 1.1$ & $1.2 \pm 1.0$ & $2.0 \pm 1.7$ & $228 \pm 344$ & $96 \pm 136$ & $7 \pm 6$ & $25 \pm 29$ \\
\hline $\mathrm{pH}$ & - & $2.5 \pm 0.7$ & $2.3 \pm 0.5$ & $2.0 \pm 0.5$ & $-0.52 \pm 0.62$ & $-0.77 \pm 0.67$ & $-0.38 \pm 0.64$ & $0.61 \pm 0.71$ \\
\hline
\end{tabular}

hydrogen ions in the aqueous phase of aerosols per unit of air volume $\left(\mathrm{nmol} \mathrm{m}^{-3}\right)$. The free acidity of aerosols is an important parameter for describing atmospheric processes and the environmental impact of atmospheric aerosol (Seinfeld and Pandis, 2006); it affects many of the acidity-dependent heterogeneous chemical processes on the aerosol surfaces, such as the oxidation of $\mathrm{SO}_{2}$, the hydrolysis of $\mathrm{N}_{2} \mathrm{O}_{5}$, and the formation of organic aerosols (Pathak et al., 2009, and reference therein). Moreover, the acidity ratio (Engelhart et al., 2011) or neutralization ratio (NR) (Bencs et al., 2008),

$\mathrm{NR}=\frac{\left[\mathrm{NH}_{4}^{+}\right]}{\left[\mathrm{SO}_{4}^{2-}\right]+\left[\mathrm{NO}_{3}^{-}\right]}$, was used to describe the aerosol acidity, expressing the degree of neutralization of sulfate and nitrate by ammonium (expressed as equivalent). In this way NR expresses the aerosol acidity characteristics by considering only the possible neutralization of the two major inorganic acids (nitric and sulfuric) with ammonium.

Table 1 reports the mean values of aerosol acidity parameters $\left(\mathrm{NR},\left[\mathrm{H}^{+}\right]_{\text {Strong }},\left[\mathrm{H}^{+}\right]_{\text {Free }}, \mathrm{pH}\right)$ in the three sites during the four periods studied. On both annual and seasonal basis, ammonium seems to almost completely neutralize sulfates and nitrates because NR averages are equal to 1 within variability, or slightly less. However, in winter NR assumes a value greater than 1 in UBG and IND, revealing an excess of ammonium in those sites. The highest average values of $\left[\mathrm{H}^{+}\right]_{\text {Strong }}$ and $\left[\mathrm{H}^{+}\right]_{\text {Free }}$ were recorded in spring and winter, 
whereas the $\mathrm{pH}$ had similar values in all seasons and sites. In summer higher aerosol acidity, exceeding $300 \mathrm{nmol} \mathrm{m}^{-3}$, can lead to an enhancement in photochemical activities (Liu et al., 1996). However, the observed average aerosol acidity was largely below this limit $\left(\max \left[\mathrm{H}^{+}\right]_{\text {Strong }}=174.3\right.$ $\mathrm{nmol} \mathrm{m}{ }^{-3}$ ). On this basis the measured aerosol acidity characteristics cannot lead to serious atmospheric implications.

IND had the largest seasonal variation of acidity with $\mathrm{pH}$ values higher in the cold and lower in the warm periods. The free acidity $\left(\left[\mathrm{H}^{+}\right]_{\text {Free }}\right)$ accounted for $19 \%, 18 \%$ and $12 \%$ of the strong acidity $\left(\left[\mathrm{H}^{+}\right]_{\text {Strong }}\right)$ in SRC, UBG and IND, respectively, as an annual average, whereas $\mathrm{pH}$ values ranging between 2.0 (IND summer) and 3.9 (IND spring) were observed.

In Table 2 summer data have been compared with those of Pathak et al. (2009). The study area is clearly less polluted with respect to Chinese cities reported in the literature, and the levels of $\left[\mathrm{H}^{+}\right]_{\text {Strong }}$ and $\left[\mathrm{H}^{+}\right]_{\text {Free }}$ are much lower than those presented in aforementioned work. Nevertheless, the percentage of $\left[\mathrm{H}^{+}\right]_{\text {Free }}$ to $\left[\mathrm{H}^{+}\right]_{\text {Strong }}$ is comparable to that observed in Lanzhou (11\%).

\subsection{Ammonium nitrate formation}

Ammonium nitrate is formed in presence of high ammonia and $\mathrm{HNO}_{3}$ concentrations, low temperature and high humidity (Stockwell et al., 2000; Salvador et al., 2004; Pathak et al., 2009). At low $\mathrm{NH}_{3}$ concentrations, the neutralization of acidic sulfate by ammonia is favored over the formation of ammonium nitrate, which involves a homogeneous reaction between ammonia and nitric acid. $\left[\mathrm{NH}_{4}^{+}\right] /\left[\mathrm{SO}_{4}^{2-}\right]$ molar ratio is commonly used to define ammonium nitrate formation in different environmental and chemical conditions. Several studies (Pathak et al., 2004, 2009; Arsene et al., 2010; Huang et al., 2011) report an increase of nitrate concentration for $\left[\mathrm{NH}_{4}^{+}\right] /\left[\mathrm{SO}_{4}^{2-}\right]>1.5$. In samples characterized by $\left[\mathrm{NH}_{4}^{+}\right] /\left[\mathrm{SO}_{4}^{2-}\right]>1.5$, ammonium stabilizes nitrate, whereas at $\left[\mathrm{NH}_{4}^{+}\right] /\left[\mathrm{SO}_{4}^{2-}\right]<1.5$, nitrate neutralization may depend on: (i) gas-phase reaction between $\mathrm{HNO}_{3}$ and sea-salt particles (e.g., $\mathrm{NaCl}+\mathrm{HNO}_{3(\mathrm{~g})} \rightarrow \mathrm{NaNO}_{3}+\mathrm{HCl}_{(\mathrm{g})}$ ) or fine crustal particles (e.g., $\mathrm{CaCO}_{3}$ ); (ii) heterogeneous hydrolysis of $\mathrm{N}_{2} \mathrm{O}_{5}$ during nighttime on pre-existing ammonium sulfate particles in high relative humidity conditions. The aforementioned articles reported that the $\left[\mathrm{NH}_{4}^{+}\right] /\left[\mathrm{SO}_{4}^{2-}\right]$ molar ratio of 1.5 was used to fix a limit for the ammonium excess, enabling the ammonium nitrate formation following the sulfate neutralization and defined as

$\operatorname{excess}\left[\mathrm{NH}_{4}^{+}\right]=\left(\frac{\left[\mathrm{NH}_{4}^{+}\right]}{\left[\mathrm{nssSO}_{4}^{2-}\right]}-1.5\right) \cdot\left[\mathrm{nssSO}_{4}^{2-}\right]$.

Although the aforementioned studies used the $\left[\mathrm{NH}_{4}^{+}\right] /\left[\mathrm{SO}_{4}^{2-}\right]$ molar ratio of 1.5 , in this study the threshold value appears to be different. In fact, by plotting the nitrate-to-sulfate molar ratio as a function of ammoniumto-sulfate molar ratio (Fig. 3a), a clear change of slope in the

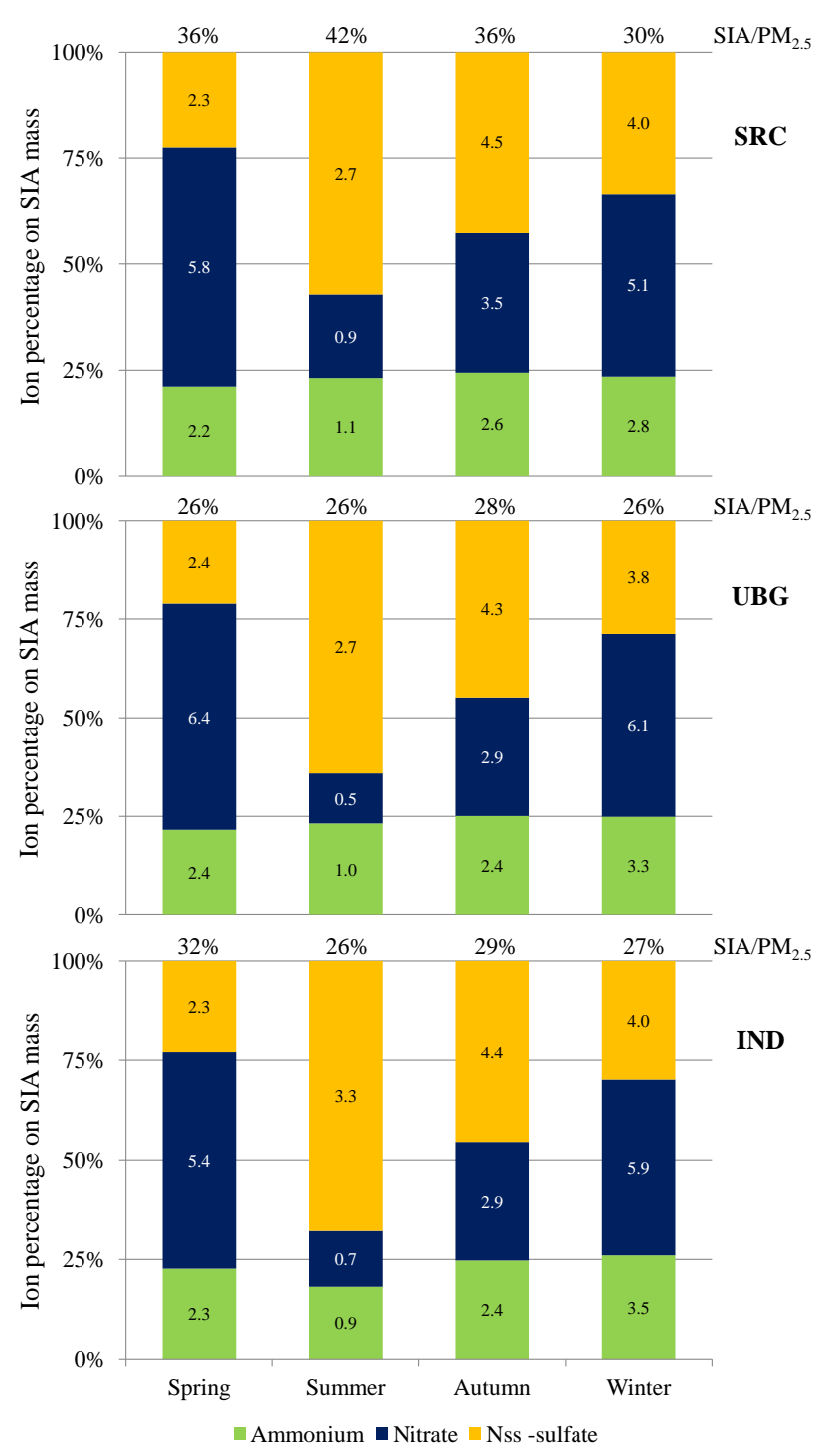

Fig. 2. Relative seasonal contribution of ammonium, nitrate and nss-sulfate on SIA at each sampling site. The percentage at the top of each bar represents the SIA contribution on $\mathrm{PM}_{2.5}$. The measure inside the bars represents the average concentration $\left(\mu \mathrm{g} \mathrm{m}^{-3}\right)$.

experimental data trend was observed in correspondence of the $\left[\mathrm{NH}_{4}^{+}\right] /\left[\mathrm{SO}_{4}^{2-}\right]$ molar ratio of 2 , instead of 1.5 . At this value each mole of sulfate removes 2 moles of ammonium and the solid or aqueous $\left(\mathrm{NH}_{4}\right)_{2} \mathrm{SO}_{4}$ is the preferred form of sulfate. Therefore, the uptake of nitric acid was observed to be significant at a molar ratio of 2 , while ammonium sulfate was in a metastable phase. The E-AIM4 output shows that the aerosol is present only in the liquid phase when the relative humidity exceeds $80 \%$, whereas the coexistence of solid and liquid phases occurs for $\mathrm{RH}<80 \%$ with the solid phase being mainly composed of $\left(\mathrm{NH}_{4}\right)_{2} \mathrm{SO}_{4}$ and $\mathrm{Na}_{2} \mathrm{SO}_{4} \cdot\left(\mathrm{NH}_{4}\right)_{2} \mathrm{SO}_{4} \cdot 4 \mathrm{H}_{2} \mathrm{O}$. 
Table 3. Mean and standard deviation for $\mathrm{PM}_{2.5}\left(\mu \mathrm{g} \mathrm{m}^{-3}\right), \mathrm{NO}_{3}^{-}\left(\mu \mathrm{g} \mathrm{m}^{-3}\right)$, nssSO $\mathrm{S}_{4}^{2-}\left(\mu \mathrm{gm}^{-3}\right)$, molar ratios $\left[\mathrm{NH}_{4}^{+}\right] /\left[\mathrm{nssSO}_{4}^{2-}\right]$ and $\left[\mathrm{NO}_{3}^{-}\right] /\left[\mathrm{nssSO}_{4}^{2-}\right]$ and environmental conditions.

\begin{tabular}{cccccccc}
\hline \multirow{2}{*}{ Group } & $\mathrm{PM}_{2.5}$ & $\mathrm{NO}_{3}^{-}$ & $\mathrm{nssSO}_{4}^{2-}$ & $\frac{\left[\mathrm{NH}_{4}^{+}\right]}{\left[\mathrm{nssSO}_{4}^{2-}\right]}$ & $\frac{\left[\mathrm{NO}_{3}^{-}\right]}{\left[\mathrm{nssSO}_{4}^{2-}\right]}$ & Temperature $\left({ }^{\circ} \mathrm{C}\right)$ & Relative humidity $(\%)$ \\
\hline 1 & $22 \pm 13$ & $2 \pm 2$ & $3 \pm 3$ & $2 \pm 1$ & $1 \pm 1$ & $16 \pm 8$ & $78 \pm 12$ \\
2 & $43 \pm 18$ & $6 \pm 2$ & $3 \pm 2$ & $7 \pm 2$ & $4 \pm 2$ & $8 \pm 6$ & $84 \pm 10$ \\
3 & $82 \pm 24$ & $18 \pm 5$ & $5 \pm 2$ & $7 \pm 2$ & $6 \pm 2$ & $8 \pm 6$ & $89 \pm 6$ \\
\hline
\end{tabular}
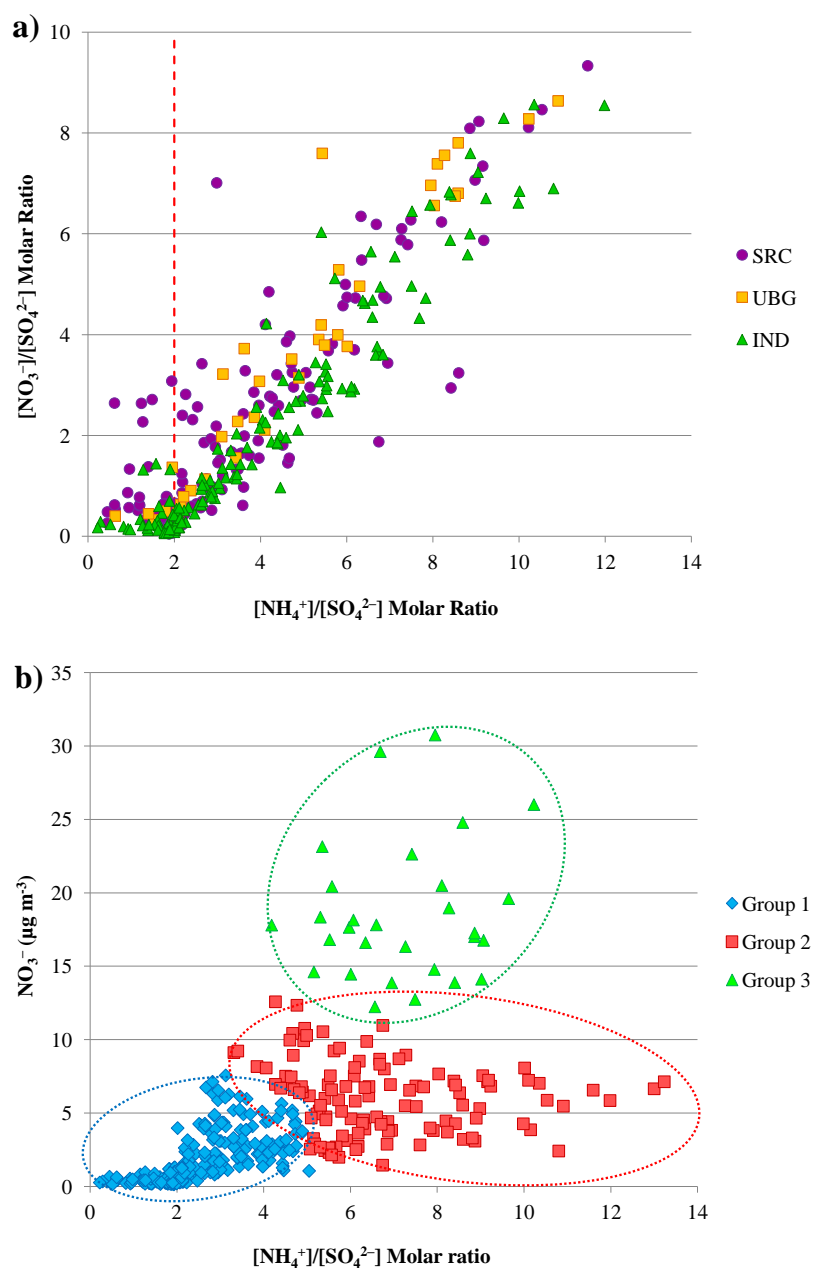

Fig. 3. Nitrate-to-sulfate molar ratio as a function of ammonium-tosulfate molar ratio (a) and nitrate-to-sulfate molar ratio as a function of nitrate showing the differences among the groups identified by the cluster analysis (b).

To better investigate the sulfate-nitrate-ammonium system, the subsequent SIA generation processes and the factors possibly inducing the change in our $\left[\mathrm{NH}_{4}^{+}\right] /\left[\mathrm{SO}_{4}^{2-}\right]$ molar ratio threshold, a chemometric approach was applied on the experimental data. A $q$-mode cluster analysis using Ward's hierarchical agglomerative clustering method and the squared Euclidean distance measure was performed on $\mathrm{NO}_{3}^{-}$and
$\left[\mathrm{NH}_{4}^{+}\right] /\left[\mathrm{SO}_{4}^{2-}\right]$ ratios to highlight the $\left[\mathrm{NH}_{4}^{+}\right] /\left[\mathrm{SO}_{4}^{2-}\right]$ limit ratio. Three groups of samples have been identified by applying a normalized $\left(D_{\text {link }} / D_{\max } \cdot 100\right)$ cut off of $25 \%$, which represents the similarity value. The $25 \%$ cut-off value, representing the scaled to 100 linkage distance $\left(\mathrm{D}_{\text {link }} / \mathrm{D}_{\max } \cdot 100\right)$ has been chosen amongst other cut-off criteria. It permits a good interpretation of experimental data and enables to obtain three statistically different groups of samples characterized by high inner homogeneity and outer heterogeneity. The difference between the identified groups was evidenced by a one-way ANOVA ( $p$-value $<0.05$ ) and is graphically highlighted in the plot of nitrate as a function of ammonium-to-sulfate molar ratio (Fig. 3b). Average concentrations of $\mathrm{PM}_{2.5}, \mathrm{NO}_{3}^{-}, \mathrm{nssSO}_{4}^{2-},\left[\mathrm{NH}_{4}^{+}\right] /\left[\mathrm{nssSO}_{4}^{2-}\right]$ and $\left[\mathrm{NO}_{3}^{-}\right] /\left[\mathrm{nssSO}_{4}^{2-}\right]$ ratios, and average meteorological parameters (temperature and relative humidity) were computed for each group (Table 3$)$.

Group $1(N=297)$ is composed of samples collected in spring $(N=51)$, summer $(N=95)$, autumn $(N=98)$ and winter $(N=51)$ and accounts for $2 / 3$ of all collected samples. Generally, the data are characterized by low $\mathrm{PM}_{2.5}$ and $\mathrm{NO}_{3}^{-}$levels. Sulfate presents higher concentration than $\mathrm{NO}_{3}^{-}$, and the $\left[\mathrm{NO}_{3}^{-}\right] /\left[\mathrm{nssSO}_{4}^{2-}\right]$ ratio is about 1 . These samples show the lower $\left[\mathrm{NH}_{4}^{+}\right] /\left[\mathrm{nssSO}_{4}^{2-}\right]$ ratios (average $\sim 2$ ) and about half of the samples present a ratio less than 2, indicating a deficit of $\mathrm{NH}_{4}^{+}$. This group of samples therefore represents samples collected under ammonium-poor conditions, and was interpreted as a consequence of a more photochemically active atmosphere, characteristic of the warmer periods when an enhanced generation of oxidants (mainly $\cdot \mathrm{OH}$ and $\mathrm{O}_{3}$ ) occurs. Moreover, high temperature, low relative humidity and reduced availability of $\mathrm{NH}_{4}^{+}$do not favor the production of $\mathrm{NH}_{4} \mathrm{NO}_{3}$.

Groups $2(N=118)$ and $3(N=30)$ are mainly found in spring and winter samples. With respect to group 1 , group 2 presents similar $\mathrm{nsSOO}_{4}^{2-}$ average concentrations but higher availability of $\mathrm{NH}_{4}^{+}$and lower temperature that favor higher $\mathrm{NO}_{3}^{-}$concentrations. Samples of group 3 show the highest $\mathrm{NO}_{3}^{-}$concentrations and $\left[\mathrm{NO}_{3}^{-}\right] /\left[\mathrm{nssSO}_{4}^{2-}\right]$ molar ratios despite the concentration of $\mathrm{nssSO}_{4}^{2-}$, and the $\left[\mathrm{NH}_{4}^{+}\right] /\left[\mathrm{nssSO}_{4}^{2-}\right]$ molar ratios are similar to group 2. This may be due to more favorable conditions for the formation of ammonium nitrate (low temperature and high relative 


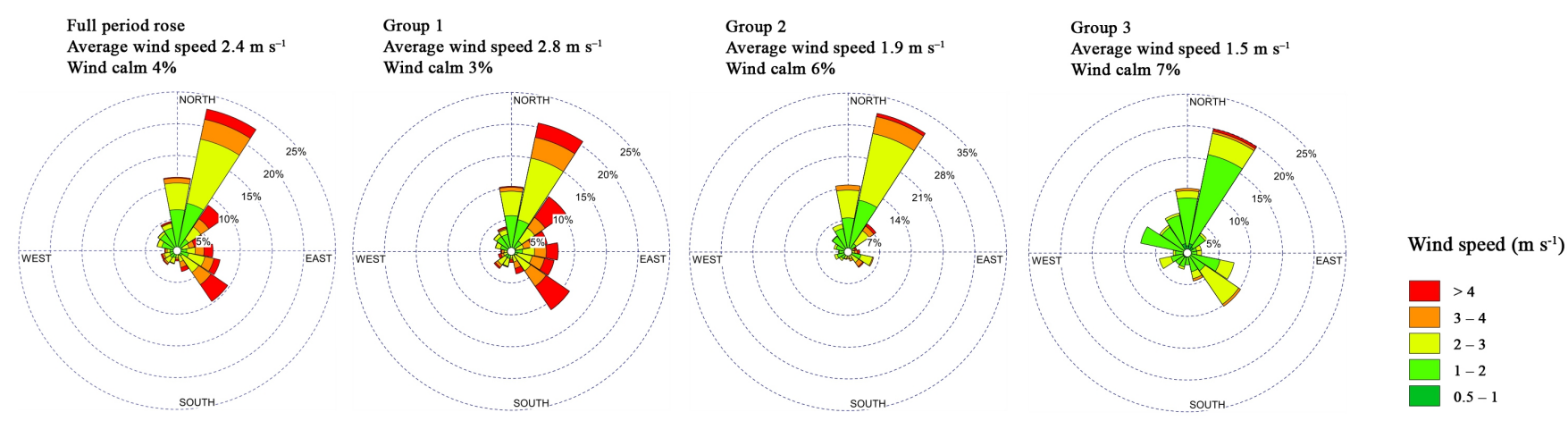

Fig. 4. Wind rose computed for each group identified by qHCA for UBG site.

humidity), to a greater availability of $\mathrm{HNO}_{3}$ from higher emissions of $\mathrm{NO}_{\mathrm{x}}$ (peculiar in cold period) and/or a more oxidizing atmosphere, which favors the formation of nitric acid from nitrogen oxides.

\subsection{Sulfur and nitrogen oxidation ratios}

Sulfur oxidation (SOR) and nitrogen oxidation ratios (NOR) have been used to evaluate the degree of atmospheric conversion of $\mathrm{SO}_{2}$ to $\mathrm{nssSO}_{4}^{2-}$ and of $\mathrm{NO}_{2}$ to $\mathrm{NO}_{3}^{-}$in terms of oxidation and partitioning (e.g., Wang et al., 2005; Bencs et al., 2008; Gu et al., 2011). The SOR expresses the degree of oxidation of sulfur as the ratio of sulfate sulfur to total sulfur (sulfate plus sulfur dioxide). Similarly, the NOR expresses the degree of oxidation of nitrogen as the ratio of nitrate nitrogen to total nitrogen (nitrate plus nitrogen dioxide) (Lin , 2002):

$$
\begin{aligned}
\mathrm{SOR} & =\frac{n-\mathrm{nssSO}_{4}^{2-}}{n-\mathrm{nssSO}_{4}^{2-}+n-\mathrm{SO}_{2}} \\
\mathrm{NOR} & =\frac{n-\mathrm{NO}_{3}^{-}}{n-\mathrm{NO}_{3}^{-}+n-\mathrm{NO}_{2}},
\end{aligned}
$$

where $n$ is the number of moles of sulfur and nitrogen. SOR and NOR consider only the aerosol fraction and not the total (gas + aerosol) $\mathrm{HNO}_{3}$ or $\mathrm{H}_{2} \mathrm{SO}_{4}$. Nevertheless, these oxidation ratio represent a useful tool to evaluate the degree of atmospheric conversion of $\mathrm{SO}_{2}$ and $\mathrm{NO}_{2}$ based on readily available data such as those from air quality networks.

SOR values were higher than 0.1 both in UBG and IND (Table 1), showing that $\mathrm{SO}_{2}$ is photochemically oxidized in the atmosphere (Bencs et al., 2008; Ohta and Okita, 1990). The highest SOR values were observed during autumn and winter in IND. This may be due to specific sampling site characteristics, e.g., the closeness to a coal power plant, whose $\mathrm{SO}_{2}$ emissions can be quickly transformed into $\mathrm{nssSO}_{4}^{2-}$, and to long range transport processes carrying secondary sulfates (Bencs et al., 2008). The highest NOR values were observed in spring and winter due to favorable conditions (low temperature and high relative humidity) for gas- to-particle conversion processes, in particular for ammonium nitrate formation.

In Veneto the main emission facilities emitting $\mathrm{SO}_{2}$ are represented by mineral oil and gas refineries (39.9\%), manufacture of glass $(32.5 \%)$, thermal power stations and other combustion installations $(22.9 \%$ ) (E-PRTR, 2012). Most of these activities are localized in Venice, where $79 \%$ of $\mathrm{SO}_{2}$ emission has been estimated deriving from energy production (ISPRA, 2012). Despite this the levels of $\mathrm{SO}_{2}$ and sulfate are not much higher than in other urban and industrial areas in the Veneto region and in Europe. In Table 4 a comparison is reported between $\mathrm{SO}_{2}$ and sulfate concentrations detected in this study and in other areas. Compared with other European studies, the levels of sulfate are similar, but $\mathrm{SO}_{2}$ concentrations are generally lower than those observed in other regions.

Wang et al. (2005) observed a positive correlation between SOR and temperature. This suggests a possible oxidation mechanism of $\mathrm{SO}_{2}$ to $\mathrm{SO}_{4}^{2-}$ because the local gasphase oxidation of $\mathrm{SO}_{2}$ by $\mathrm{OH}$ radical, followed by the condensation or absorption into the particle phase, is a strong function of temperature (Seinfeld and Pandis, 2006). In this study no significant correlations (at $p<0.05$ ) were observed between SOR, sulfate and temperature $\left(r_{\text {temperature-SOR }}=\right.$ $\left.0.06, r_{\text {temperature-sulfate }}=0.12\right)$, and between $\mathrm{SO}_{2}, \mathrm{SOR}$ and $\mathrm{PM}_{2.5}\left(r_{\mathrm{PM}_{-} \mathrm{SO}_{2}}=0.04, r_{\mathrm{PM}-\mathrm{SOR}}=0.31\right)$. This excluded a gas-phase oxidation occurring locally. Conversely, a negative significant correlation between temperature and NOR $(r=-0.5)$ has been observed, suggesting that $\mathrm{NO}_{2}$ in situ produced could undergo a gas-phase oxidation. $\mathrm{PM}_{2.5}$ concentrations are strongly correlated with $\mathrm{NO}_{3}^{-}(r=0.9), \mathrm{NH}_{4}^{+}$ $(r=0.9), \mathrm{NO}_{2}(r=0.7)$ and NOR $(r=0.8)$. This highlights that the PM increments are related to those of nitrate, ammonium, nitrogen oxides and NOR. On this basis, nitrate formation can occur at a local level due to local phase oxidation of $\mathrm{NO}_{2}$ influencing the PM mass variation.

With the aim of highlighting the relationship between PM, ions, gases and environmental conditions, a q-mode hierarchical cluster analysis (using Ward's agglomerative method 
Table 4. Comparison between $\mathrm{SO}_{2}$ and sulfate concentration detected in this study and in other areas. (a) Sulfate concentration values have been provided by ARPAV - Regional Service Laboratories; (b) $\mathrm{SO}_{2}$ concentration values have been provided by ARPAV - Department of Treviso.

\begin{tabular}{|c|c|c|c|c|c|}
\hline Location & Site type & Sampling period (from-to) & Compound & Average concentration $\left(\mu \mathrm{g} \mathrm{m}^{-3}\right)$ & Reference \\
\hline Venice - UBG & Urban background & all samples & Sulfate- $\mathrm{SO}_{2}$ & $3.3-3.7$ & This study \\
\hline Venice - IND & Industrial & all samples & Sulfate- $\mathrm{SO}_{2}$ & $3.6-5.6$ & \\
\hline Venice - SRC & Rural background & all samples & Sulfate & 3.5 & \\
\hline \multirow[t]{4}{*}{ Flanders, Belgium } & Industrial & $19 / 12 / 2002-23 / 02 / 2003$ & Sulfate- $\mathrm{SO}_{2}$ & $2.7-34$ & \multirow[t]{4}{*}{ Bencs et al. (2008) } \\
\hline & Urban & $10 / 02 / 2003-07 / 04 / 2003$ & Sulfate- $\mathrm{SO}_{2}$ & $4.3-18$ & \\
\hline & Suburban & $11 / 12 / 2001-30 / 01 / 2002$ & Sulfate- $\mathrm{SO}_{2}$ & $4.5-19$ & \\
\hline & Rural & $27 / 02 / 2002-15 / 05 / 2002$ & Sulfate & 0.8 & \\
\hline Elche, Spain & Urban background & October 2003-September 2004 & Sulfate & $\begin{array}{l}4.3\left(\text { in } \mathrm{PM}_{10}\right) \\
3.3\left(\text { in } \mathrm{PM}_{2.5}\right)\end{array}$ & Galindo et al. (2008) \\
\hline \multirow[t]{3}{*}{ Thessaloniki, Greece } & Urban & July 1997-July 1998 & Sulfate & 4.8 & \multirow[t]{3}{*}{ Tsitouridou et al. (2003) } \\
\hline & Urban/Industrial & July 1997-July 1998 & Sulfate & 7.2 & \\
\hline & Residential & July $1997-J u l y ~ 1998$ & Sulfate & 7.2 & \\
\hline Istanbul, Turkey & & $2002-2010$ & $\mathrm{SO}_{2}$ & $\begin{array}{c}16.6 \text { (EU side }) \\
10.9 \text { (Asian side })\end{array}$ & Ozcan et al. (2012) \\
\hline \multicolumn{6}{|l|}{ Veneto cities } \\
\hline Padova & Urban background & 29/01/10 -01/03/10, 22/07/10 -23/08/10 & $\mathrm{SO}_{2}$ & 1 & ARPAV (2012) \\
\hline Verona & Urban traffic & Full year -2010 & $\mathrm{SO}_{2}$ & 3 & \\
\hline Belluno & Urban backgorund & Full year - 2011 & Sulfate- $\mathrm{SO}_{2}$ & $2.2(\mathrm{a})-1$ & \\
\hline Vicenza & Urban traffic & Full year - 2011 & $\mathrm{SO}_{2}$ & 1 & \\
\hline Treviso & Urban background & Full year - 2011 & Sulfate- $\mathrm{SO}_{2}$ & $3.1(a)-4(b)$ & \\
\hline
\end{tabular}

Table 5. Average values for each group identified by qHCA analysis. SRC data have not been considered in this analysis because the concentrations of $\mathrm{SO}_{2}$ and $\mathrm{NO}_{2}$ are not available for this site.

\begin{tabular}{lccccccccccc}
\hline & $N$ & $\mathrm{PM}_{2.5}$ & $\mathrm{NH}_{4}^{+}$ & $\mathrm{nssSO}_{4}^{2-}$ & $\mathrm{SO}_{2}$ & $\mathrm{SOR}$ & $\mathrm{NO}_{3}^{-}$ & $\mathrm{NO}_{2}$ & $\mathrm{NOR}$ & $T$ & $\mathrm{RH}$ \\
\hline UBG & & & & & & & & & & & \\
\hline All & 139 & 34.5 & 2.4 & 3.3 & 3.7 & 0.4 & 4.2 & 43.9 & 0.05 & 13.2 & 79.5 \\
Group 1 & 89 & 21.1 & 1.2 & 1.9 & 3.8 & 0.3 & 2 & 39.9 & 0.03 & 14.7 & 77.3 \\
Group 2 & 38 & 48.2 & 3.6 & 5.9 & 3.2 & 0.6 & 4.5 & 47.2 & 0.06 & 11.2 & 81.6 \\
Group 3 & 12 & 90.1 & 7.4 & 5.8 & 5 & 0.5 & 20.3 & 63.5 & 0.19 & 8.7 & 88.5 \\
\hline IND & & & & & & & & & & & \\
\hline All & 145 & 33.1 & 2.3 & 3.6 & 5.6 & 0.3 & 3.7 & 38.1 & 0.06 & 13.5 & 78.6 \\
Group 1 & 76 & 21.9 & 1.2 & 3.4 & 6 & 0.3 & 1.1 & 33.7 & 0.02 & 18.8 & 72.6 \\
Group 2 & 36 & 32.4 & 2.2 & 2.3 & 3.9 & 0.3 & 4.5 & 36.9 & 0.08 & 8.6 & 87.2 \\
Group 3 & 33 & 59.7 & 4.7 & 5.4 & 6.7 & 0.5 & 8.7 & 49.2 & 0.12 & 6.6 & 82.9 \\
\hline
\end{tabular}

and the squared Euclidean distance measures) was performed on a standardized (mean $=0$; standard deviation $=1$ ) dataset, including $\mathrm{PM}_{2.5}, \mathrm{NH}_{4}^{+}, \mathrm{nssSO}_{4}^{2-}, \mathrm{SO}_{2}, \mathrm{SOR}, \mathrm{NO}_{3}^{-}, \mathrm{NO}_{2}$, NOR, temperature and relative humidity. Three groups of samples were extracted with similar characteristics (Table 5), and each group was subsequently interpreted according to wind speed and direction (Fig. 4), as described in Squizzato et al. (2012). Group 1 links most of the samples $\left(N_{\mathrm{UBG}}=89\right.$, $N_{\text {IND }}=76$ ), showing lower NOR values and concentration of PM, SIA ions and $\mathrm{NO}_{2}$, and higher temperatures than the other two groups. The wind rose is similar to that of the full period. In group 2 increase in concentrations of $\mathrm{PM}_{2.5}$, $\mathrm{NO}_{3}^{-}, \mathrm{nssSO}_{4}^{2-}, \mathrm{NH}_{4}^{+}$and $\mathrm{NO}_{2}$ and also in NOR values is observed. As to the environmental conditions, group 2 presents lower temperature and higher relative humidity than group 1 , and the wind rose shows a decrease in the average wind speed. Group 3 identifies the heavy pollution events, combining samples characterized by the highest concentrations of all variables, lowest temperature and wind speed, and high relative humidity. An increase of $\mathrm{NO}_{2}$ accounts for the increased $\mathrm{NO}_{3}^{-}$concentration both in the UBG and IND site. This relationship was not observed between $\mathrm{SO}_{2}$ and $\mathrm{nssSO}_{4}^{2-}$ in UBG. Conversely, in the IND site increasing concentrations of $\mathrm{SO}_{2}$ correspond to an increase of sulfate.

In previous studies carried out in the Venice area (Masiol et al., 2010; Squizzato et al., 2012; Masiol et al., 2012b), the variations in sulfate and nitrate concentrations were investigated by using a clustering approach on back trajectories and wind rose analysis. Results attributed the sulfate variations to regional transport processes rather than to a local origin. In this scenario, considering the low correlation between PM and $\mathrm{SO}_{2}$ and between sulfate and temperature, $\mathrm{nsSSO}_{4}^{2-}$ can 
be mainly attributed to regional processes. Differently, considering the high correlation between $\mathrm{PM}$, nitrate, $\mathrm{NO}_{2}$, NOR and temperature, nitrate formation can occur at local scale, being favored by conditions with higher levels of $\mathrm{NO}_{2}$ and relative humidity and lower temperatures. These studies also pointed out that heavy pollution events occur in days when, due to scarce ventilation and low temperature, pollutants are trapped and SIA generation processes are favored.

\section{Conclusions}

The formation of secondary inorganic particles and aerosol acidity in the atmosphere was studied by investigating the relationship between gaseous precursors and environmental conditions. The water soluble inorganic component represents a significant fraction of $\mathrm{PM}_{2.5}$. In particular, SIA accounts for $9.5 \mu \mathrm{g} \mathrm{m}^{-3}$ (27\% of $\mathrm{PM}_{2.5}$ mass) in UBG, $9.6 \mu \mathrm{g} \mathrm{m}^{-3}(28 \%)$ in IND and $9.5 \mu \mathrm{g} \mathrm{m}^{-3}$ (36\%) in SRC. Collected particles are acidic, in particular in spring and winter, with low $\mathrm{pH}$ values.

Nitrate concentrations increase for $\left[\mathrm{NH}_{4}^{+}\right] /\left[\mathrm{nsSSO}_{4}^{2-}\right]>$ 2 , and the excess ammonium, which is necessary for the ammonium nitrate formation, was in the 1:1 ratio with nitrate. The highest nitrate concentrations were observed during the cold period due to more favorable conditions for the formation of ammonium nitrate (low temperature and high relative humidity), to a greater availability of $\mathrm{HNO}_{3}$ from higher emissions of $\mathrm{NO}_{\mathrm{x}}$ (peculiar in cold period) and/or a more oxidizing atmosphere favoring the formation of nitric acid from nitrogen oxides. In these conditions also, the highest NOR values were observed and $\mathrm{PM}_{2.5}, \mathrm{NO}_{3}^{-}$and $\mathrm{NO}_{2}$ values were strongly correlated. On this basis it is apparent that nitrate formation can occur at local scale, enhanced by high availability of $\mathrm{NO}_{2}$ and conditions of low temperature and high relative humidity, whereas $\mathrm{nssSO}_{4}^{2-}$ is mainly transported by regional processes. High pollution events are the result of the concomitant occurrence of low-mobility atmospheric conditions, that tend to trap pollutants, and low temperature that enhances SIA generation processes. The obtained results can be useful for a better understanding of the aerosol dynamics in the Po Valley.

Acknowledgements. This study presents a part of the results obtained in the framework of the project "Study of secondary particulate matter in the Venice area", financially supported by Ente della Zona Industriale di Porto Marghera (http://www.entezona.it/). The authors are grateful to Francesco Pinna, Michela Signoretto and Elena Ghedini for their analytical support and the Comando Zona Fari e Segnalamenti Marittimi di Venezia for logistics.

Edited by: L. M. Russell

\section{References}

ARPAV (Environmental Protection Agency of Veneto Region): The quality of the air in the municipality of Venice, ARPAV annual report 2009, 113, available online: http://www.comune.venezia. it/flex/cm/pages/ServeBLOB.php/L/IT/IDPagina/29764, 2010a, last access: 31 January 2012.

ARPAV (Environmental Protection Agency of Veneto Region): Regional relation of air quality, ARPAV report 2009, 59 pp., available online: http://www.arpa.veneto.it/Download/ Relazione_regionale_aria_2009.pdf, 2010b, last access: 31 January 2012.

ARPAV (Environmental Protection Agency of Veneto Region) http://www.arpa.veneto.it/temi-ambientali/aria/riferimenti/ documenti, last access: September 2012.

Ansari, A. S. and Pandis, S. N.: Prediction of multicomponent inorganic atmospheric aerosol behavior, Atmos. Environ., 33, 745757, 1999.

Ansari, A. S. and Pandis, S. N.: The effect of metastable equilibrium states on the partitioning of nitrate between the gas and aerosol phases, Atmos. Environ., 34, 157-168, 2000.

Arsene, C., Olariu, R. I., Zarmpas, P., Kanakidou, M., and Mihalopoulos, N.: Ion composition of coarse and fine particles in Iasi, North-Eastern Romania: implications for aerosols chemistry in the area, Atmos. Environ., 45, 906-911, 2010.

Baek, B. H., Aneja, V. P. and Tong, Q.: Chemical coupling between ammonia, acid gases, and fine particles, Environ. Pollut., 129, 89-98, 2004.

Bäumer, D., Vogel, B., Versick, S., Rinke, R., Möhler, O., and Schnaiter, M.: Relationship of visibility, aerosol optical thickness and aerosol size distribution in an ageing air mass over SouthWest Germany, Atmos. Environ., 42, 989-998, 2008.

Bencs, L., Ravindra, K., de Hoog, J., Rasoazanany, E. O., Deutsch, F., Bleux, N., Berghmans, P., Roekens, E., Krata, A., and Van Grieken, R.: Mass and ionic composition of atmospheric fine paticles over Belgium and their relation with gaseous air pollutant, J. Environ. Monit., 10, 1148-1157, 2008.

Clegg, S. L., Brimblecombe, P., and Wexler, A. S.: A thermodynamic model of the system $\mathrm{H}^{+}-\mathrm{NH}_{4}^{+}-\mathrm{SO}_{4}^{2-}-\mathrm{NO}_{3}^{-}-\mathrm{H}_{2} \mathrm{O}$ at tropospheric temperatures, J. Phys. Chem. A, 102, 2137-2154, 1998.

Dassios, K. G. and Pandis, S. N.: The mass accommodation coefficient of ammonium nitrate aerosol, Atmos. Environ., 33, 29933003, 1999.

EC (European Commission): Council Directive 2008/50/EC of the European Parliament and of the Council of 21 May 2008 on ambient air quality and cleaner air for Europe, Official J. Eur. Commun., L152/1, 2008.

EEA (European Environment Agency) AirBase - The European air quality database: available online: http://www.eea.europa.eu/ themes/air/airbase, last access: 31 January 2012.

Engelhart, G. J., Hildebrandt, L., Kostenidou, E., Mihalopoulos, N., Donahue, N. M., and Pandis, S. N.: Water content of aged aerosol, Atmos. Chem. Phys., 11, 911-920, doi:10.5194/acp-11911-2011, 2011.

E-PRTR: The European Pollutant Release and Transfer Register (EPRTR), http://prtr.ec.europa.eu/, last access: September 2012.

Forster, P., Ramaswamy, V., Artaxo, P., Berntsen, T., Betts, R., Fahey, D. W., Haywood, J., Lean, J., Lowe, D. C., Myhre, G., 
Nganga, J., Prinn, R., Raga, G., Schulz, M., and Van Dorland, R.: Changes in atmospheric constituents and in radiative forcing, in: Climate Change 2007: The Physical Science Basis, Contribution of Working Group I to the Fourth Assessment Report of the Intergovernmental Panel on Climate Change, edited by: Solomon, S., Qin, D., Manning, M., Chen, Z., Marquis, M., Averyt, K. B., Tignor, M., and Miller, H. L., Cambridge University Press, Cambridge, UK, and New York, USA, 2007.

Friese, E. and Ebel, A.: Temperature dependent thermodynamic model of the system $\mathrm{H}^{+}-\mathrm{NH}_{4}^{+}-\mathrm{Na}^{+}-\mathrm{SO}_{4}^{2-}-\mathrm{NO}_{3}^{-}-\mathrm{Cl}^{-}-\mathrm{H}_{2} \mathrm{O}$, J. Phys. Chem. A, 114, 11595-11631, 2010.

Galindo, N., Nicolás, J. F., Yubero, E., Caballero, S., Pastor, C. and Crespo, J.: Factors affecting levels of aerosol sulfate and nitrate on the Western Mediterranean coast, Atmos. Res., 88, 305-313, 2008.

Gu, J., Bai, Z., Li, W., Wu, L., Liu, A., Dong, H., and Xie, Y.: Chemical composition of $\mathrm{PM}_{2.5}$ during winter in Tianjin, China, Particuology, 9, 215-221, 2011.

Huang, X., Qiu, R., Chan, C. K., and Pathak, R. K.: Evidence of high $\mathrm{PM}_{2.5}$ strong acidity in ammonia-rich atmosphere of Guangzhou, China: Transition in pathways of ambient ammonia to form aerosol ammonium at $\left[\mathrm{NH}_{4}^{+}\right] /\left[\mathrm{SO}_{4}^{2-}\right]=1.5$, Atmos. Res., 99, 488-495, 2011.

ISPRA (Italian Institute for Environmental Protection and Research) disaggregated emission inventory 2005: available online: http://www.sinanet.isprambiente.it/it/inventaria/ disaggregazione_prov2005/, last access: 1 March 2012.

Larssen, T., Lydersen, E., Tang, D. G., He, Y., Gao, J. X., Liu, H. Y., Duan, L., Seip, H. M., Vogt, R. D., Mulder, J., Shao, M., Wang, Y. H., Shang, H., Zhang, X. S., Solberg, S., Aas, W., Okland, T., Eilertsen, O., Angell, V., Liu, Q. R., Zhao, D. W., Xiang, R. J., Xiao, J. S., and Luo, J. H.: Acid rain in China, Environ. Sci. Technol., 40, 418-425, 2006.

Lin, J.J.: Characterization of water-soluble ion species in urban ambient particles, Environ. Int., 28, 55-61, 2002.

Lippmann, M., Xiong, J. Q., and Li, W.: Development of a continuous monitoring system for $\mathrm{PM}_{10}$ and components of $\mathrm{PM}_{2.5}$, Appl. Occupat. Environ. Hyg., 15, 57-67, 2000.

Liu, L.-J. S., Burton, R., Wilson, W. and Koutrakis, P.: Comparison of aerosol acidity in urban and semirural environments, Atmos. Environ., 30, 1237-1245, 1996.

Lonati, G., Giugliano, M., and Ozgen, S.. Primary and secondary components of $\mathrm{PM}_{2.5}$ in Milan (Italy), Environ. Int., 34, 665670, 2008.

Masiol, M., Rampazzo, G., Ceccato, D., Squizzato, S., and Pavoni, B.: Characterization of $\mathrm{PM}_{10}$ sources in a coastal area near Venice (Italy): an application of factor-cluster analysis, Chemosphere, 80, 771-778, 2010.

Masiol, M., Squizzato, S., Ceccato, D., Rampazzo, G., and Pavoni, B.: A chemometric approach to determine local and regional sources of $\mathrm{PM}_{10}$ and its geochemical composition in a coastal area, Atmos. Environ., 54, 127-133, 2012.

Masiol, M., Squizzato, S., Ceccato, D., Rampazzo, G., and Pavoni, B.: Determining the influence of different atmospheric circulation patterns on $\mathrm{PM}_{10}$ chemical composition in a source apportionment study, Atmos. Environ., 63, 117-124, 2012.

Nava, S., Becherini, F., Bernardi, A., Bonazza, A., Chiari, M., García-Orellana, I., Lucarelli, F., Ludwig, N., Migliori, A., Sabbioni, C., Udisti, R., Valli, G., and Vecchi, R.: An integrated approach to assess air pollution threats to cultural heritage in a semi-confined environment: the case study of Michelozzo's Courtyard in Florence (Italy), Sci. Total Environ., 408, 1403$1413,2010$.

Ohta, S. and Okita, T.: A chemical characterization of atmospheric aerosol in Sapporo, Atmos. Environ., 24A, 815-822, 1990.

Ozcan, H. K.: Long Term variations of the atmospheric air pollutants in Istanbul City, Int. J. Environ. Res., 9, 781-790, 2012.

Pathak, R. K. and Chan, C. K.: Inter-particle and gas-particle interactions in sampling artifacts of $\mathrm{PM}_{2.5}$ in filter-based samplers, Atmos. Environ., 39, 1597-1607, 2005.

Pathak, R. K., Louie, P. K. K., and Chan, C. K.: Characteristics of aerosol acidity in Hong Kong, Atmos. Environ., 38, 2965-2974, 2004.

Pathak, R. K., Wu, W. S., and Wang, T.: Summertime $\mathrm{PM}_{2.5}$ ionic species in four major cities of China: nitrate formation in an ammonia-deficient atmosphere, Atmos. Chem. Phys., 9, 17111722, doi:10.5194/acp-9-1711-2009, 2009.

Pathak, R. K., Wang, T., Ho, K. F., and Lee, S. C.: Characteristics of summertime $\mathrm{PM}_{2.5}$ organic and elemental carbon in four major Chinese cities: implications of high acidity for water-soluble organic carbon (WSOC), Atmos. Environ., 45, 318-325, 2011.

Pope, C. A. III, Ezzati, M., and Dockery, D. W.: Fine-particulate air pollution and life expectancy in the United States, N. Engl. J. Med., 360, 376-386, 2009.

Prodi, F., Belosi, F., Contini, D., Santachiara, G., Di Matteo, L., Gambaro, A., Donateo, A., and Cesari, D.: Aerosol fine fraction in the Venice Lagoon: particle composition and sources, Atmos. Res., 92, 141-150, 2009.

Putaud, J. P., Raes, F., Van Digenen, R., Brüggemann, E., Facchini, M.-C., Decesari, S., Fuzzi, S., Gehrig, R., Hüglin, C., Laj, P., Lorbeer, G., Maenhaut, W., Mihalopoulos, N., Müller, K., Querol, X., Rogriguez, S., Schneider, J., Spindler, G., ten Brink, H., Tørseth, K., and Wiedensohler, A.: A European aerosol phenomenology - 2: chemical characteristics of particulate matter at kerbside, urban, rural and background sites in Europe, Atmos. Environ., 38, 2579-2595, 2004.

Putaud, J.-P., Van Dingenen, R., Alastuey, A., Bauer, H., Birmili, W., Cyrys, J., Flentje, H., Fuzzi, S., Gehrig, R., Hansson, H. C., Harrison, R. M., Herrmann, H., Hitzenberger, R., Hüglin, C., Jones, A. M., Kasper-Giebl, A., Kiss, G., Kousa, A., Kuhlbusch, T. A. J., Löschau, G., Maenhaut, W., Molnar, A., Moreno, T., Pekkanen, J., Perrino, C., Pitz, M., Puxbaum, H., Querol, X., Rodriguez, S., Salma, I., Schwarz, J., Smolik, J., Schneider, J., Spindler, G., ten Brink, H., Tursic, J., Viana, M., Wiedensohler, A., and Raes, F.: A European aerosol phenomenology - 3: physical and chemical characteristics of particulate matter from 60 rural, urban, and kerbside sites across Europe, Atmos. Environ., 44, 1308-1320, 2010.

Querol, X., Alastuey, A., Ruiz, C. R., Artiñano, B., Hansson, H. C., Harrison, R. M., Buringh, E., ten Brink, H. M., Lutz, M., Bruckmann, P., Straehl, P., and Schneider, J.: Speciation and origin of $\mathrm{PM}_{10}$ and $\mathrm{PM}_{2.5}$ in selected European cities, Atmos. Environ., 38, 6547-6555, 2004.

Rampazzo, G., Masiol, M., Visin, F., Rampado, E., and Pavoni, B.: Geochemical characterization of $\mathrm{PM}_{10}$ emitted by glass factories in Murano, Venice (Italy), Chemosphere, 71, 2068-2075, 2008a.

Rampazzo, G., Masiol, M., Visin, F., and Pavoni, B.: Gaseous and $\mathrm{PM}_{10}$-bound pollutants monitored in three environmental con- 
ditions in the Venice area (Italy), Water Air Soil Pollut., 195, 161-176, 2008b.

Renner, E. and Wolke, R.: Modelling the formation and atmospheric transport of secondary inorganic aerosols with special attention to regions with high ammonia emissions, Atmos. Environ., 44, 1904-1912, 2010.

Salvador, P., Artíñano, B., Alonso, D. G., Querol, X., and Alastuey, A.: Identification and characterisation of sources of $\mathrm{PM}_{10}$ in Madrid (Spain) by statistical methods, Atmos. Environ., 38, 435-447, 2004.

Schaap, M., van Loon, M., ten Brink, H. M., Dentener, F. J., and Builtjes, P. J. H.: Secondary inorganic aerosol simulations for Europe with special attention to nitrate, Atmos. Chem. Phys., 4, 857-874, doi:10.5194/acp-4-857-2004, 2004a.

Schaap, M., Spindler, G., Schulz, M., Acker, K., Maenhaut, W., Berner, A., Wieprecht, W., Streit, N., Müller, K., Brüggemann, E., Chi, X., Putaud, J. P., Hitzenberger, R., Puxbaum, H., Baltensperger, U., and ten Brink, H.: Artefacts in the sampling of nitrate studied in the "INTERCOMP" campaigns of EUROTRAC-AEROSOL, Atmos. Environ., 38, 6487-6496, 2004b.

Seinfeld, J. H. and Pandis, S. N.: Atmospheric Chemistry and Physics - From Air Pollution to Climate Change, 2nd edn., John Wiley \& Sons, New York, USA, 2006.

Squizzato, S., Masiol, M., Innocente, E., Pecorari, E., Rampazzo, G., and Pavoni, B.: A procedure to assess local and longrange transport contributions to $\mathrm{PM}_{2.5}$ and secondary inorganic aerosol, J. Aerosol Sci., 46, 64-76, 2012.
Stockwell, W. R., Watson, J., Robinson, N. F., Steiner, W., and Sylte, W. W.: The ammonium nitrate particle equivalent of $\mathrm{NO}_{\mathrm{x}}$ emissions for wintertime conditions in Central California's San Joaquin Valley, Atmos. Environ., 34, 4711-4717, 2000.

Stockwell, W. R., Kuhns, H., Etyemezian, V., Green, M. C., Chow, J. C., and Watson, J. G.: The Treasure Valley secondary aerosol study II: modeling of the formation of inorganic secondary aerosols and precursors for Southwestern Idaho, Atmos. Environ., 37, 525-534, 2003.

Surrat, J., Wandowski, M., Offenberg, J., Jaoui, M., Kleindienst, T., Edney, E., and Seinfeld, J.: Effect of Acidity on Secondary Organic Aerosol Formation from Isoprene, Environ. Sci. Technol., 41, 5363-5369, 2007.

Tsitouridou, R., Voutsa, D., and Kouimtzis, Th.: Ionic composition of $\mathrm{PM}_{10}$ in the area of Thessaloniki, Greece, Chemosphere, 52, 883-891, 2003.

Vecchi, R., Valli, G., Fermo, P., D’Alessandro, A., Piazzalunga, A., and Bernardoni, V.: Organic and inorganic sampling artefacts assessment, Atmos. Environ., 43, 1713-1720, 2009.

Wang, Y., Zhuang, G., Tang, A., Yuan, H., Sun, Y., Chen, S., and Zheng, A.: The ion chemistry and the source of $\mathrm{PM}_{2.5}$ aerosol in Beijing, Atmos. Environ., 39, 3771-3784, 2005.

Zhang, Y., Seigneur, C., Seinfeld, J. H., Jacobson, M., Clegg, S. L., and Binkowski, F. S.: A comparative review of inorganic aerosol thermodynamic equilibrium modules: similarities, differences, and their likely causes, Atmos. Environ., 34, 117-137, 2000.

Zhang, Q., Jemenez, J. L., Worsnop, D. R., and Canagaratna, M.: A case study of urban particle acidity and its influence on secondary organic aerosol, Environ. Sci. Technol., 41, 3213-3219, 2007. 